\title{
Association between intake of dietary protein and 3 -year-change in body growth among normal and overweight 6-year-old boys and girls (CoSCIS)
}

\author{
Anneke JAH van Vught ${ }^{1,2, *}$, Berit L Heitmann ${ }^{3}$, Arie $G$ Nieuwenhuizen ${ }^{1,2}$, Margriet AB \\ Veldhorst ${ }^{1,2}$, Lars Bo Andersen ${ }^{4}$, Henriette Hasselstrom ${ }^{4}$, Robert-Jan M Brummer ${ }^{2,5}$ and \\ Margriet S Westerterp-Plantenga ${ }^{1,2}$ \\ 'Department of Human Biology, Universiteitssingel 50, PO Box 616, 6200 MD Maastricht, The Netherlands: \\ ${ }^{2} \mathrm{TI}$ Food and Nutrition, PO Box 557, 6700 AN Wageningen, The Netherlands: ${ }^{3}$ Research Unit for Dietary \\ Studies, Institute of Preventive Medicine, Copenhagen University Hospital, Copenhagen, Denmark: ${ }^{4}$ Institute of \\ Sport Science and Clinical Biomechanics, University of Southern Denmark, Odense, Denmark: ${ }^{5}$ School of Health \\ and Medical Sciences, Örebro University, Örebro, Sweden
}

Submitted 19 January 2009: Accepted 4 August 2009: First published online 17 September 2009

\begin{abstract}
Objective: Growth hormone (GH) affects linear growth and body composition, by increasing the secretion of insulin-like growth factor-I (IGF-I), muscle protein synthesis and lipolysis. The intake of protein (PROT) as well as the specific amino acids arginine (ARG) and lysine (LYS) stimulates GH/IGF-I secretion. The present paper aimed to investigate associations between PROT intake as well as intake of the specific amino acids ARG and LYS, and subsequent 3-year-change in linear growth and body composition among 6-year-old children.

Design: Children's data were collected from Copenhagen (Denmark), during 2001-2002, and again 3 years later. Boys and girls were separated into normal weight and overweight, based on BMI quintiles. Fat-free mass index (FFMI) and fat mass index (FMI) were calculated. Associations between change ( $\Delta$ ) in height, FMI and FFMI, respectively, and habitual PROT intake as well as ARG and LYS were analysed by multiple linear regressions, adjusted for baseline height, FMI or FFMI and energy intake, age, physical activity and socio-economic status.

Setting: Eighteen schools in two suburban communities in the Copenhagen (Denmark) area participated in the study.

Subjects: In all, 223 children's data were collected for the present study.

Results: High ARG intake was associated with linear growth $(\beta=1.09$ (SE 0.54), $P=0.05)$ among girls. Furthermore, in girls, $\Delta$ FMI had a stronger inverse association with high ARG intake, if it was combined with high LYS intake, instead of low LYS intake $(P=0 \cdot 03)$. No associations were found in boys.

Conclusion: In prepubertal girls, linear growth may be influenced by habitual ARG intake and body fat gain may be relatively prevented over time by the intake of the amino acids ARG and LYS.
\end{abstract}

Protein intake is associated with greater velocity of linear growth in childhood $^{(1)}$ as well as with a more beneficial body composition ${ }^{(2-4)}$. Some studies suggest that not only the amount of protein intake, but also the protein source have a regulatory effect on body growth; for instance, milk protein is strongly associated with growth in height when compared with meat or vegetable protein ${ }^{(5)}$. Growth hormone (GH) and insulin-like growth factor-I (IGF-I) play a central role in the regulation of growth in height and width ${ }^{(5,6)}$. Besides the important role of $\mathrm{GH} /$ IGF-I in regulating growth in height, it also regulates fat distribution and reduces fat mass $(\mathrm{FM})^{(7)}$. Studies show an increased lipolysis and decreased FM after GH administration $^{(8-11)}$. Dietary protein may be involved in secretion of GH and IGF-I, because protein restriction results in low IGF-I concentrations in healthy children, which returns to normal after refeeding with proteins ${ }^{(12)}$. This finding is confirmed by a study showing that milk protein, but not meat or vegetable protein, increases IGF-I concentrations and growth in height ${ }^{(5)}$.

The effects of dietary protein on IGF-I concentrations and growth ${ }^{(1,11,13,14)}$ may be mediated by a direct 
GH-releasing effect of specific amino acids ${ }^{(15-21)}$, in particular arginine (ARG) and lysine (LYS) ${ }^{(17,19,21)}$. Earlier studies suggest that the amino acid composition is crucial in understanding the mechanism through which protein may influence GH and IGF-I production with regard to growth and body composition, as specific proteins, such as gelatin protein (which is high in ARG), stimulate the GH release more potently than other protein sources ${ }^{(22)}$. However, no earlier studies have been performed investigating the relationship between the intake of specific amino acids and the development of FM and fat-free mass (FFM) in prepubertal children.

In the present study, we investigated associations between the intakes of protein (PROT) and, more specifically, the amino acids ARG and LYS in the habitual diet, and subsequent changes in linear growth, body fat and FFM, among normal weight and overweight 6-year-old boys and girls. High intakes of PROT, and more specifically, a high intake of ARG, especially in combination with a high intake of LYS, was expected to increase linear growth and the fat-free mass index (FFMI) and decrease fat mass index (FMI).

\section{Material and methods}

\section{Subjects}

The data were derived from the Copenhagen School Child Intervention Study (CoSCIS). Children from fortysix preschool classes (6-7 years of age) in eighteen schools in two suburban communities in the Copenhagen area were invited to participate in the CoSCIS. In 2000, the community of Ballerup (ten schools, twenty-seven classes) increased the number of physical exercise lessons from two to four in a week, for the first 3 years of school. The community of Taarnby (eight schools, nineteen classes) was chosen as a control, as it resembles Ballerup regarding the sociodemographic characteristics. The reported data in the present study are from the controls of this study (only community of Taarnby) ${ }^{(23,24)}$. A total of 706 children (69\% of those eligible) volunteered in the study, and written informed consent was obtained from the parents/guardians. Of these 706 children, 415 from Ballerup and 291 from Taarnby participated at baseline, 614 children were followed up at third grade. The ethics committee of Copenhagen County approved the study. The measurements were performed from December 2001 until June 2002 preschool, at the eighteen different schools and in the follow-up from September 2004 until May 2005 at third grade. All control children with complete information about food intake, physical activity (PA), socio-economic status (SES), height, weight and skinfold thickness at baseline as well as height, weight and skinfold thickness at follow-up were included. According to these inclusion criteria, ninety-four boys and 109 girls, respectively, were included.

\section{Measurements}

\section{Dietary intake}

Parents recorded the dietary intake of their child for seven consecutive days in supplied booklets with pre-coded fixed answer possibilities, supplemented with a possibility for open answers. Food portion sizes were estimated from household measures and a series of photographs. This booklet for dietary record has been developed and used in nationwide dietary surveys since $1995^{(25)}$. The pre-printed diet records were delivered by the teachers in the schools in closed envelopes addressed to each child, who brought them home. The same logistic was used for return of the completed records.

Intakes of nutrients and foods were calculated using the General Intake Estimation System (Danish Institute for Food and Veterinary Research, 2005) based on the Danish food database ${ }^{(26)}$. The researchers computed the dietary information in a database, by which it was possible to calculate nutrient information (i.e. energy content, protein content, amino acid content) of the individual food items or whole meals and diets. Corrections for losses in cooking were made when calculating nutrient contents.

Reporting of dietary intake of energy was evaluated by comparing reported energy intake (EI) with estimations of energy expenditure (based on basal metabolic rate (BMR; Harris \& Benedict) and physical activity level $(\mathrm{PAL})$ ). The PAL in children varies between 1.3 and $1 \cdot 9^{(27)}$. Children who reported an EI below BMR $\times 1 \cdot 3$ or above BMR $\times 2 \cdot 0$ were excluded.

\section{Anthropometry and other measurements}

All measurements were carried out using standardised methods, which have been described in detail elsewhere ${ }^{(23,24)}$.

Height was measured by a Harpenden stadiometer, to the nearest $1 \mathrm{~mm}$. Body weight was measured to the nearest $0 \cdot 1 \mathrm{~kg}$ using a SECA electronic scale. Both measurements were performed during school-time by experienced scientists. Bicipital, tricipital, subscapular and suprailiac skinfolds were measured with a Harpenden skinfold calliper to the nearest $1 \mathrm{~mm}$. The dominant side of the body was determined by asking the child to take a pen and write his/her name. The data shown herein represent the mean of three measurements taken on the non-dominant side of the body. The sum of four skinfolds (SFS) was used to calculate body fat percentage. Children were divided into quintiles according to their BMI, adjusted for sex and age ${ }^{(28)}$. Analyses were first performed in the whole group of girls and boys and later the groups were divided in BMI quintiles 1-4 and BMI quintile 5.

Habitual PA was measured by the MTI 7164 activity monitor (Manufactory Technology Inc., Fort Walton Beach, FL, USA). This monitor has been validated in several studies and has shown both high mechanical 
reproducibility and good validity with regard to free living conditions in children ${ }^{(24)}$. To allow familiarisation, the children had to wear the MTI monitor one day before recording. It was secured directly to the skin at the lower back using an elastic belt. The children were instructed to wear the monitor continuously except during waterbased activities or when sleeping. A mean count was calculated for each child ${ }^{(24)}$.

The classification of SES was based on information regarding the education of the mother in the household at the first measurement point, as recent studies suggest that the risk factors considered herein are more strongly associated with the SES of the mother rather than that of the father ${ }^{(29-31)}$. The education level of the mother was divided into seven categories: (1) $<7$ years education, (2) 7-8 years education, (3) 9-10 years completed elementary school, (4) 12 years high school, (5) short non-university programmes under 3 years, (6) college 3-4 years and (7) university degree over 4 years.

\section{Calculation of fat-free mass and fat mass}

The body fat percentage was estimated from the skinfold thickness using the equations from Weststrate ${ }^{(32)}$ :

(i) girls aged $2-10$ years: Fat $\%=((562-1 \cdot 1($ age -2$)) /$ D) $-(525-1 \cdot 4($ age -2$))$ and

(ii) girls aged $11-18$ years: Fat $\%=((533-7 \cdot 3$ (age $10)) / \mathrm{D})-(514-8 \cdot 0($ age -10$))$ and

(iii) boys aged $2-18$ years: Fat $\%=((562-4 \cdot 2($ age -2$)) /$ D) $-(525-4 \cdot 7($ age -2$))$

where $\mathrm{D}=$ Total body density estimated from following equations: (i) girls aged $2-10$ years: $\mathrm{D}=(1 \cdot 1315+0 \cdot 0004 \times$ $($ age -2$))-((0 \cdot 0719-0.0003 \times($ age -2$)) \times \log 4$ skin $)$ and (ii) girls aged $11-18$ years: $\mathrm{D}=(1 \cdot 1350+0 \cdot 0031 \times($ age 10) $)-((0 \cdot 0719-0 \cdot 0003 \times($ age -2$)) \times \log 4$ skin $)$ and (iii) boys aged $2-18$ years: $\mathrm{D}=(1 \cdot 1315+0 \cdot 0018 \times($ age -2$))-$ $((0 \cdot 0719-0 \cdot 0006 \times($ age -2$)) \times \log 4$ skin $)$ where Log4skin $=$ $\log (\Sigma$ mean of the four skinfold thickness).

FM and the FFM were calculated from the body weight and the estimated body fat (\%). FM and FFM were divided by squared height, to calculate FFMI and FMI, respectively ${ }^{(33)}$. These indices have been proposed as indicator of nutritional status, and because FMI + FFMI = BMI, their use allows to asses the contribution of FM and FFM to $\mathrm{BMI}^{(33)}$.

\section{Statistical analysis}

Each dietary and anthropometric variable was treated as a continuous variable. The relationship between change $(\Delta)$ in height, FMI or FFMI, and intake of PROT as well as the intake of ARG or LYS at 6 years of age was assessed by a multiple regression model including the covariates: baseline height, FMI or FFMI, age, EI, PA and SES. The interaction of ARG with LYS was estimated in a model with the same covariates as the model described above. This model was converted to the final regression model, by dividing LYS into low and high LYS intake. Low LYS intake was defined as LYS intake below median and high LYS intake as LYS intake above median. Since there was an interaction between the independent variables PROT, ARG, LYS and gender, data of boys and girls were analysed separately. After analysing data of boys and girls separately, they were divided in either the 1-4th quintile of BMI (leaner children) or in the 5th quintile of BMI (heavier children) to investigate if there is a difference in growth influenced by protein intake between the leaner children and the heavier children. To test the significance of the contribution of the variables, an F-test was used. The characteristics are expressed as mean (SD). All other values are expressed as mean (SE). A $P$ value $<0 \cdot 05$ was considered as indicating statistical significance. All statistical analyses were performed using SPSS for Windows, version 14.0 (SPSS, Chicago, IL, USA).

\section{Results}

The characteristics of the children, grouped by study year, gender and quintile of BMI are shown in Table 1.

The results are summarised in Tables 2 and 3, with $\Delta$ height, $\Delta$ FMI and $\Delta$ FFMI as dependent variables and habitual intake of PROT as well as the specific amino acids ARG and LYS, and the interaction between them, as independent variables. Adjustments were made for the covariates: baseline height, FMI or FFMI, age, EI, PA and SES.

\section{Association between change in beight and babitual intake of protein, and specifically arginine and lysine intake}

Among girls, growth in height was associated with a high intake of ARG $(\beta=1.09$ (sE 0.54$), P<0.05)$, but intake of PROT or LYS was not associated with changes in linear growth (Table 2). Among boys, this association did not reach significance.

\section{Association between change in FMI and babitual intake of protein, and specifically arginine and lysine intake}

Significant associations were found between changes in FMI and habitual intakes of PROT as well as for the specific amino acids ARG or LYS separately, or combined $(\beta=-0.03$ (sE 0.01$), \quad P=0.01 ; \beta=-0.51 \quad$ (SE 0.11$)$, $P=0 \cdot 01 ; \beta=-0.30$ (se $0 \cdot 06), P=0 \cdot 01 ;$ respectively), among girls with a BMI in the 5th percentile, but not among the girls with a BMI in the 1-4th quintile (Tables 2 and 3). Among boys, no associations were found between $\Delta F M I$ and the intake of PROT; significant associations however were found between $\Delta \mathrm{FMI}$ and the intake of the specific amino acid LYS, among boys with a BMI in the 5 th quintile $(\beta=-0.57$ (SE 0.13$)$, $P=0 \cdot 01$ ) (Table 2). 
Table 1 Characteristics of boys and girls aged 6 years and 9 years according to BMI quintiles

\begin{tabular}{|c|c|c|c|c|c|c|c|c|}
\hline & \multicolumn{2}{|c|}{ Boys $^{*}(n 73)$} & \multicolumn{2}{|c|}{ Boyst ( $n$ 21) } & \multicolumn{2}{|c|}{ Girls* $^{*}(n$ 89) } & \multicolumn{2}{|c|}{ Girlst ( $n$ 20) } \\
\hline & Mean & SD & Mean & SD & Mean & SD & Mean & SD \\
\hline \multicolumn{9}{|l|}{6 -year-old } \\
\hline Weight (kg) & $23 \cdot 4$ & $2 \cdot 4$ & $28 \cdot 7$ & $3 \cdot 9$ & $22 \cdot 4$ & $2 \cdot 5$ & $28 \cdot 9$ & $3 \cdot 5$ \\
\hline Height $(\mathrm{cm})$ & $122 \cdot 8$ & $5 \cdot 3$ & $125 \cdot 4$ & $5 \cdot 9$ & $121 \cdot 1$ & $4 \cdot 3$ & $123 \cdot 7$ & $5 \cdot 0$ \\
\hline Sum of skinfold (mm) & 30 & 6 & 46 & 14 & 35 & 8 & 59 & 15 \\
\hline BMI $\left(\mathrm{kg} / \mathrm{m}^{2}\right)$ & $15 \cdot 4$ & $0 \cdot 7$ & $18 \cdot 2$ & $1 \cdot 1$ & $15 \cdot 2$ & $0 \cdot 7$ & $18 \cdot 9$ & 0.9 \\
\hline FFMI $\left(\mathrm{kg} / \mathrm{m}^{2}\right)$ & $13 \cdot 3$ & $0 \cdot 8$ & $14 \cdot 2$ & $1 \cdot 0$ & $11 \cdot 4$ & $0 \cdot 7$ & $12 \cdot 6$ & 0.6 \\
\hline FMI $\left(\mathrm{kg} / \mathrm{m}^{2}\right)$ & $2 \cdot 1$ & $0 \cdot 7$ & $4 \cdot 0$ & $1 \cdot 2$ & $3 \cdot 8$ & $0 \cdot 8$ & $6 \cdot 3$ & $1 \cdot 3$ \\
\hline Physical activity score (counts) & 126 & 40 & 131 & 40 & 116 & 26 & 117 & 26 \\
\hline SES $1 / 2 / 3 / 4 / 5 / 6 / 7(\%)$ & \multicolumn{2}{|c|}{$5 / 9 / 7 / 25 / 29 / 10 / 13$} & \multicolumn{2}{|c|}{ 0/12/4/28/36/16/4 } & \multicolumn{2}{|c|}{$4 / 3 / 8 / 20 / 42 / 15 / 8$} & \multicolumn{2}{|c|}{$5 / 5 / 14 / 24 / 24 / 5 / 23$} \\
\hline Energy intake $(\mathrm{MJ} / \mathrm{d})$ & $8 \cdot 3$ & $1 \cdot 5$ & $8 \cdot 2$ & $2 \cdot 1$ & $7 \cdot 7$ & $1 \cdot 5$ & $7 \cdot 5$ & 1.5 \\
\hline PROT intake $(\mathrm{g} / \mathrm{d})$ & $69 \cdot 5$ & $17 \cdot 8$ & $71 \cdot 3$ & $15 \cdot 7$ & $63 \cdot 4$ & $15 \cdot 2$ & $59 \cdot 7$ & $13 \cdot 7$ \\
\hline ARG intake (g/d) & $2 \cdot 8$ & 0.9 & $3 \cdot 0$ & $1 \cdot 0$ & $2 \cdot 5$ & $0 \cdot 6$ & $2 \cdot 3$ & 0.5 \\
\hline LYS intake (g/d) & $4 \cdot 5$ & $1 \cdot 3$ & $4 \cdot 6$ & $1 \cdot 1$ & $4 \cdot 1$ & $1 \cdot 1$ & $3 \cdot 8$ & $1 \cdot 1$ \\
\hline \multicolumn{9}{|l|}{ 9-year-old } \\
\hline Weight (kg) & $31 \cdot 9$ & $4 \cdot 3$ & $40 \cdot 7$ & $7 \cdot 2$ & $31 \cdot 2$ & $5 \cdot 3$ & $40 \cdot 7$ & $6 \cdot 1$ \\
\hline Height $(\mathrm{cm})$ & $138 \cdot 9$ & $6 \cdot 1$ & $141 \cdot 7$ & $6 \cdot 7$ & $137 \cdot 8$ & $4 \cdot 3$ & 141.5 & $5 \cdot 7$ \\
\hline Sum of skinfold (mm) & 26 & 9 & 46 & 18 & 32 & 10 & 62 & 22 \\
\hline BMI $\left(\mathrm{kg} / \mathrm{m}^{2}\right)$ & $16 \cdot 5$ & 0.9 & $20 \cdot 3$ & $1 \cdot 4$ & $16 \cdot 3$ & $1 \cdot 1$ & $19 \cdot 1$ & $1 \cdot 5$ \\
\hline FFMI $\left(\mathrm{kg} / \mathrm{m}^{2}\right)$ & $15 \cdot 2$ & $1 \cdot 1$ & $17 \cdot 4$ & $1 \cdot 6$ & $12 \cdot 6$ & 0.9 & $12 \cdot 3$ & $0 \cdot 7$ \\
\hline $\mathrm{FMI}\left(\mathrm{kg} / \mathrm{m}^{2}\right)$ & $1 \cdot 3$ & $0 \cdot 7$ & $2 \cdot 8$ & $1 \cdot 2$ & $3 \cdot 7$ & $1 \cdot 2$ & $6 \cdot 8$ & $1 \cdot 9$ \\
\hline
\end{tabular}

FFMI, fat-free mass index; FMI, fat mass index; SES, socio-economic status; PROT, total protein; ARG, arginine; LYS, lysine.

*BMl-quintiles 1-4.

tBMI-quintile 5 .

Table 2 Adjusted models showing the associations between both ARG and LYS ( $\mathrm{g} / \mathrm{d})$ intakes and changes in height ( $\mathrm{m}$ ), FMI and FFMI $\left(\mathrm{kg} / \mathrm{m}^{2}\right)$

\begin{tabular}{|c|c|c|c|c|c|c|c|c|c|}
\hline & \multicolumn{3}{|c|}{ Boys ( $n 94)$} & \multicolumn{3}{|c|}{ Boys $^{*}(n 73)$} & \multicolumn{3}{|c|}{ Boyst (n 21) } \\
\hline & $\beta$ & SE & $P$ & $\beta$ & SE & $P$ & $\beta$ & SE & $P$ \\
\hline \multicolumn{10}{|c|}{ Height (m) } \\
\hline PROT & 0.04 & 0.02 & $0 \cdot 11$ & 0.04 & 0.03 & $0 \cdot 11$ & $-0 \cdot 10$ & 0.09 & 0.92 \\
\hline ARG & $0 \cdot 61$ & 0.36 & $0 \cdot 10$ & $0 \cdot 60$ & 0.46 & $0 \cdot 19$ & $0 \cdot 84$ & $0 \cdot 88$ & 0.36 \\
\hline LYS & 0.34 & 0.25 & $0 \cdot 18$ & 0.38 & 0.29 & $0 \cdot 19$ & -0.09 & 0.82 & 0.92 \\
\hline \multicolumn{10}{|c|}{$\mathrm{FMl}\left(\mathrm{kg} / \mathrm{m}^{2}\right)$} \\
\hline PROT & 0.00 & 0.00 & 0.79 & 0.00 & 0.00 & 0.51 & -0.04 & 0.02 & 0.12 \\
\hline ARG & 0.02 & 0.05 & 0.72 & -0.02 & 0.05 & $0 \cdot 60$ & -0.02 & $0 \cdot 21$ & 0.92 \\
\hline LYS & -0.01 & 0.04 & 0.78 & -0.09 & 0.03 & 0.74 & -0.57 & 0.13 & 0.01 \\
\hline \multicolumn{10}{|c|}{ FFMI $\left(\mathrm{kg} / \mathrm{m}^{2}\right)$} \\
\hline PROT & 0.02 & 0.01 & 0.22 & 0.00 & 0.01 & 0.88 & 0.00 & 0.07 & 0.97 \\
\hline$A R G$ & 0.40 & 0.23 & 0.09 & 0.00 & 0.21 & 1.00 & 0.60 & 0.64 & 0.39 \\
\hline \multirow[t]{3}{*}{ LYS } & $0 \cdot 16$ & $0 \cdot 16$ & $0 \cdot 35$ & -0.02 & $0 \cdot 14$ & 0.90 & $-0 \cdot 70$ & $0 \cdot 76$ & 0.40 \\
\hline & \multicolumn{3}{|c|}{ Girls (n 109) } & \multicolumn{3}{|c|}{ Girls* (n 89) } & \multicolumn{3}{|c|}{ Girlst (n 20) } \\
\hline & $\beta$ & SE & $P$ & $\beta$ & SE & $P$ & $\beta$ & SE & $P$ \\
\hline \multicolumn{10}{|c|}{ Height (m) } \\
\hline PROT & 0.02 & 0.03 & 0.59 & 0.02 & 0.03 & 0.63 & $0 \cdot 12$ & $0 \cdot 12$ & 0.33 \\
\hline ARG & $1 \cdot 09$ & 0.54 & 0.05 & $1 \cdot 15$ & 0.58 & 0.05 & $3 \cdot 16$ & $2 \cdot 04$ & $0 \cdot 17$ \\
\hline LYS & 0.21 & 0.32 & 0.52 & $0 \cdot 19$ & 0.35 & 0.59 & $1 \cdot 69$ & $1 \cdot 20$ & 0.20 \\
\hline \multicolumn{10}{|c|}{ FMl $\left(\mathrm{kg} / \mathrm{m}^{2}\right)$} \\
\hline PROT & 0.00 & 0.01 & 0.79 & 0.00 & 0.01 & 0.88 & -0.03 & 0.01 & 0.01 \\
\hline ARG & -0.09 & 0.23 & 0.72 & 0.00 & 0.29 & 0.99 & -0.51 & $0 \cdot 11$ & 0.01 \\
\hline LYS & -0.06 & 0.13 & 0.66 & -0.01 & 0.17 & 0.98 & $-0 \cdot 30$ & 0.06 & 0.01 \\
\hline \multicolumn{10}{|c|}{ FFMI $\left(\mathrm{kg} / \mathrm{m}^{2}\right)$} \\
\hline PROT & -0.01 & 0.01 & 0.26 & 0.00 & 0.01 & 0.80 & -0.06 & 0.03 & 0.13 \\
\hline ARG & -0.04 & $0 \cdot 16$ & 0.82 & $0 \cdot 10$ & $0 \cdot 18$ & 0.59 & -0.63 & 0.51 & 0.28 \\
\hline LYS & -0.09 & 0.09 & 0.31 & -0.02 & 0.11 & 0.85 & -0.42 & 0.29 & 0.22 \\
\hline
\end{tabular}

ARG, arginine; LYS, lysine; FMI, fat mass index; FFMI, fat-free mass index; PROT, total protein.

*BMI-quintiles $1-4$.

+BMI-quintile 5 .

Further analyses showed that ARG and LYS were not independently related to changes in $\Delta$ FMI $(P=0 \cdot 03)$ (Table 3). The interaction analysis showed that among girls with a BMI in the 1-4th quintile, a stronger inverse correlation was found between $\triangle F M I$ and ARG intake if LYS intake was high, than if LYS intake was low $(P=0 \cdot 03$; Fig. 1$)$. 
Table 3 Final models between the interaction of ARG and LYS $(\mathrm{g} / \mathrm{d})$ and height $(\mathrm{m})$, FMl and FFMI $\left(\mathrm{kg} / \mathrm{m}^{2}\right)$

\begin{tabular}{|c|c|c|c|c|c|c|c|c|c|c|c|c|}
\hline & \multicolumn{4}{|c|}{ Boys ( $n$ 94) } & \multicolumn{4}{|c|}{ Boys $^{*}(n 73)$} & \multicolumn{4}{|c|}{ Boyst (n 21) } \\
\hline & $\beta$ & SE & $P$ & $A \times L \neq$ & $\beta$ & SE & $P$ & $A \times L \neq$ & $\beta$ & SE & $P$ & $A \times L \ddagger$ \\
\hline \multicolumn{13}{|l|}{ Height (m) } \\
\hline Low LYS§ & $1 \cdot 03$ & 0.94 & 0.28 & \multirow[t]{2}{*}{0.53} & $1 \cdot 01$ & $1 \cdot 06$ & 0.35 & \multirow[t]{2}{*}{0.42} & $1 \cdot 41$ & $3 \cdot 70$ & 0.71 & \multirow[t]{2}{*}{$0 \cdot 85$} \\
\hline High LYS\| & 0.44 & 0.51 & 0.39 & & 0.17 & 0.73 & $0 \cdot 82$ & & 0.64 & $1 \cdot 13$ & 0.59 & \\
\hline \multicolumn{13}{|l|}{ FMI $\left(\mathrm{kg} / \mathrm{m}^{2}\right)$} \\
\hline Low LYS§ & -0.01 & $0 \cdot 13$ & 0.94 & \multirow[t]{2}{*}{$0 \cdot 65$} & -0.08 & $0 \cdot 11$ & 0.48 & \multirow[t]{2}{*}{0.58} & 0.40 & 0.36 & 0.35 & \multirow[t]{3}{*}{$0 \cdot 31$} \\
\hline $\begin{array}{r}\text { High LYS\| } \\
\text { FFMI }\left(\mathrm{kg} / \mathrm{m}^{2}\right)\end{array}$ & 0.05 & 0.07 & 0.50 & & -0.01 & 0.07 & 0.85 & & -0.08 & $0 \cdot 15$ & 0.65 & \\
\hline $\begin{array}{c}\text { LFIVII }\left(\mathrm{kg} / \mathrm{m}^{-}\right) \\
\text {Low LYS }\end{array}$ & 0.88 & 0.59 & $0 \cdot 14$ & \multirow{2}{*}{$0 \cdot 36$} & $0 \cdot 71$ & 0.48 & $0 \cdot 15$ & \multirow{2}{*}{0.07} & $2 \cdot 65$ & $2 \cdot 10$ & 0.30 & \\
\hline \multirow[t]{2}{*}{ High LYS\| } & 0.34 & $0 \cdot 32$ & 0.29 & & $-0 \cdot 17$ & 0.32 & 0.59 & & $1 \cdot 48$ & 0.98 & 0.23 & 0.65 \\
\hline & \multicolumn{4}{|c|}{ Girls (n 109) } & \multicolumn{4}{|c|}{ Girls* (n 89) } & \multicolumn{4}{|c|}{ Girlst (n 20) } \\
\hline \multicolumn{13}{|l|}{ Height (m) } \\
\hline Low LYS§ & $3 \cdot 62$ & $1 \cdot 18$ & 0.00 & \multirow[t]{3}{*}{$0 \cdot 65$} & $3 \cdot 37$ & $1 \cdot 17$ & 0.01 & \multirow[t]{2}{*}{0.55} & $17 \cdot 18$ & $10 \cdot 80$ & 0.19 & \multirow[t]{2}{*}{$0 \cdot 68$} \\
\hline High LYS\| & $4 \cdot 09$ & $1 \cdot 40$ & 0.01 & & $4 \cdot 02$ & $1 \cdot 42$ & 0.01 & & $14 \cdot 35$ & $14 \cdot 61$ & 0.38 & \\
\hline \multicolumn{12}{|l|}{ FMI $\left(\mathrm{kg} / \mathrm{m}^{2}\right)$} & \\
\hline Low LYS§ & 0.22 & 0.50 & 0.66 & \multirow[t]{2}{*}{0.03} & 0.21 & 0.56 & $0 \cdot 71$ & \multirow[t]{2}{*}{0.03} & -0.41 & $2 \cdot 84$ & 0.91 & \multirow[t]{2}{*}{0.92} \\
\hline $\begin{array}{r}\text { High LYS } \\
\text { FFMl }\left(\mathrm{kg} / \mathrm{m}^{2}\right)\end{array}$ & $-0 \cdot 74$ & $0 \cdot 60$ & 0.22 & & -0.90 & 0.69 & $0 \cdot 20$ & & -0.57 & $3 \cdot 75$ & $0 \cdot 91$ & \\
\hline Low LYS & 0.50 & $0 \cdot 36$ & $0 \cdot 17$ & \multirow[t]{2}{*}{0.93} & 0.50 & 0.37 & $0 \cdot 18$ & \multirow[t]{2}{*}{$0 \cdot 78$} & $8 \cdot 24$ & $5 \cdot 50$ & 0.38 & \multirow[t]{2}{*}{0.51} \\
\hline High LYS\| & 0.47 & 0.43 & 0.28 & & $0 \cdot 41$ & 0.46 & 0.37 & & $10 \cdot 17$ & $6 \cdot 78$ & 0.37 & \\
\hline
\end{tabular}

ARG, arginine; LYS, lysine; FMI, fat mass index; FFMI, fat-free mass index.

${ }^{*}$ BMl-quintiles 1-4.

†BMI-quintile 5.

¥Arginine $\times$ Lysine interactions.

$\S L Y S<4.25 \mathrm{~g} / \mathrm{d}$.

$\| \mathrm{LYS}>4.25 \mathrm{~g} / \mathrm{d}$.

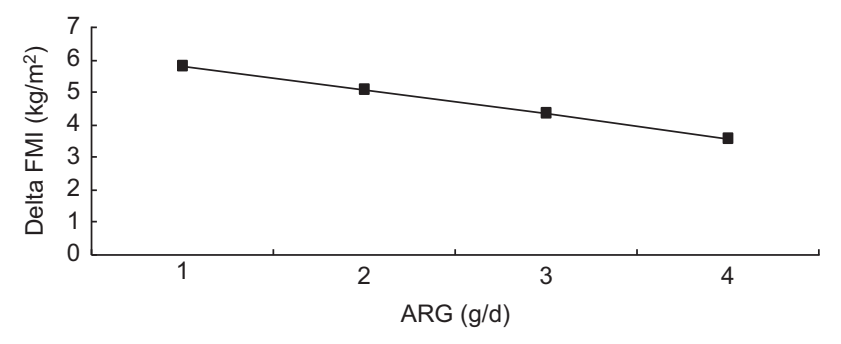

Fig. 1 Interaction of ARG and LYS $(\mathrm{g} / \mathrm{d})$ and $\mathrm{FMI}\left(\mathrm{kg} / \mathrm{m}^{2}\right)$ among girls (- - high LYS; ARG, arginine; LYS, lysine; FMI, fat mass index)

\section{Association between change in FFMI and habitual intake of protein, and specifically arginine and lysine intake}

No associations were found between change in FFMI and habitual intake of PROT, ARG or LYS (Table 2).

\section{Discussion}

The present study shows that linear growth as well as the development of body composition may be influenced by habitual dietary intake of the amino acids ARG and LYS, among prepubertal girls.

The association between linear growth and the intake of ARG may be explained by the stimulation of the somatotropic axis by ARG, as ARG is a potent stimulator of $\mathrm{GH}$ secretion ${ }^{(16)}$ and $\mathrm{GH}$ plays an important role in linear growth ${ }^{(5,34)}$. This association reached significance only in girls $(P<0 \cdot 05)$, but the association had the same direction and magnitude in boys also $(P=0 \cdot 10)$. For the intake of PROT in general, or LYS, the association with linear growth was weaker, indicating that, in particular, ARG is an important dietary determinant of linear growth. We could, however, not confirm the involvement of the somatotropic axis within the present study, as plasma IGF-I concentrations were not available in this cohort. Earlier studies investigating the effects of dietary protein source on growth in height showed increased IGF-I concentrations as well as growth in height after intake of milk protein, but not after intake of animal or vegetable protein, which suggests an influence of specific amino acid concentrations or combinations influencing IGF-I concentrations and growth in height ${ }^{(5,13)}$.

Besides the association between ARG and linear growth, high intake of ARG, combined with high intake of LYS, is associated with a relative decrease in FMI. This may also be explained by the stimulating effects of these amino acids on $\mathrm{GH}$ secretion ${ }^{(16,17)}$, as $\mathrm{GH}$ is known to decrease body FMI $^{(35)}$. The subgroup analyses were based on small numbers that may have prevented the finding of significant associations between protein intake and FMI for the boys. All associations, however, were in the same direction for boys and girls, which suggest that protein was of importance for growth.

The interactions between the amino acids suggest that the effect of proteins is depending on the available amount and combination of specific amino acids, such as 
ARG and LYS, as demonstrated in the present study. The somatotropic regulation of growth and body composition could thus be modulated by privileged amino acids and proteins $^{(1)}$. In a recent study, we found remarkable differences in the potency of various dietary proteins to stimulate the somatotropic activity, with gelatin (high in ARG) showing the largest increase on GH secretion among other proteins ${ }^{(22)}$.

In the present study, the mean intake of PROT per day was 66 (sD 16) g/d $(2.6 \mathrm{~g} / \mathrm{kg} / \mathrm{d})$, which is considerably above the requirement of $0.95 \mathrm{~g} / \mathrm{kg} / \mathrm{d}$ (Third National Health and Nutrition Examination Survey, NHANES III). However, the same protein intake was also seen in other studies among Danish children ${ }^{(1,21)}$. The mean intake of ARG per day was $2 \cdot 6(\mathrm{SD} 0 \cdot 8) \mathrm{g} / \mathrm{d}$ and for LYS $4 \cdot 3(\mathrm{SD} 1 \cdot 2)$ $\mathrm{g} / \mathrm{d}$, which is in accordance with the requirements for adults (NHANES III). For children, no accepted requirement values are published (WHO report, 2007). ARG is present in large amounts in products like nuts, seeds, fish and meat, and particularly high concentrations are present in walnuts, sesame seeds and shellfish. LYS is present in meat and milk products and is found in particularly high amounts in beef and cheese.

It should be noted that information on dietary intakes was obtained using a $7 \mathrm{~d}$ food record, and that measurement error may have occurred, as also indicated by the lower total EI among the children in the 5th BMI quintile compared with the lean children. However, all dietary instruments used to assess habitual diet intake have random as well as specific errors ${ }^{(36)}$. On the other hand, studies have shown that although EI is frequently under-reported, protein reporting is more accurate ${ }^{(37)}$. Therefore, we believe that the present data, especially with regard to protein intake, indeed largely reflect true intake levels. Moreover, in order to be able to take EI into account as covariate, we excluded clear underreporters and over-reporters. Misreporters consisted of a few under-reporters; they were clearly inaccurate reporters. Over-reporting occurred more often, as parents/caretakers reported on children ${ }^{(38,39)}$. The ability of the parents to quantify portion sizes causes errors in quantification; for instance, parents report what they believe their child should eat, rather than what they actually do eat ${ }^{(38)}$.

The results of the present study suggest that a physiological role of habitual PROT intake on growth in height and the regulation of body composition in later life may depend on the amount and the combination of specific amino acids, and may add to our understanding of how to perform future dietary intervention among prepubertal children. This has to be further investigated by experimental designs.

In conclusion, in prepubertal girls, linear growth may be influenced by habitual ARG intake and body fat gain may be relatively prevented over time by a high intake of the combination of the amino acids ARG and LYS.

\section{Acknowledgements}

The authors would like to acknowledge the members of the Copenhagen School Child Intervention Study for making their data available. The authors wish to acknowledge the helpful assistance from statistician Michael Gamborg in analysing data. This research received no specific grant from any funding agency in the public, commercial or not-forprofit sectors. List of author contributions: A.J.A.H.V.V., B.L.H., A.G.N., R.-J.M.B. and M.S.W.-P. designed the study. L.B.A. and H.H. collected the data. A.J.A.H.V.V. and B.L.H. analysed the data and wrote the manuscript, and A.G.N., L.B.A., H.H., M.A.B.V., R.-J.M.B. and M.S.W.-P. contributed to interpretation of the data and reviewed the manuscript. The study was executed under the supervision of B.L.H., A.G.N., R.-J.M.B. and M.S.W.-P. None of the authors have any conflict of interests to declare.

\section{References}

1. Hoppe C, Molgaard C, Thomsen BL, Juul A \& Michaelsen KF (2004) Protein intake at 9 mo of age is associated with body size but not with body fat in 10-y-old Danish children. Am J Clin Nutr 79, 494-501.

2. van Vught J, Heitmann B, Nieuwenhuizen A, Veldhorst M, Brummer R \& Westerterp-Plantenga M (2008) Association between dietary protein and 6y-change in body composition among normal and overweight 9y-old boys and girls (EYHS). Clin Nutr (In the Press)

3. Weigle DS, Breen PA, Matthys CC, Callahan HS, Meeuws KE, Burden VR \& Purnell JQ (2005) A high-protein diet induces sustained reductions in appetite, ad libitum caloric intake, and body weight despite compensatory changes in diurnal plasma leptin and ghrelin concentrations. Am J Clin Nutr 82, 41-48.

4. Westerterp-Plantenga MS, Lejeune MP, Nijs I, van Ooijen M \& Kovacs EM (2004) High protein intake sustains weight maintenance after body weight loss in humans. Int J Obes Relat Metab Disord 28, 57-64.

5. Hoppe C, Udam TR, Lauritzen L, Molgaard C, Juul A \& Michaelsen KF (2004) Animal protein intake, serum insulinlike growth factor I, and growth in healthy $2 \cdot 5$-y-old Danish children. Am J Clin Nutr 80, 447-452.

6. Rolland-Cachera M (1995) Prediction of adult body composition from infant and child measurements. In Body Composition Techniques in Health and Disease, pp. 100-145 [PSW Davies and TJ Cole, editors]. Cambridge, UK: Cambridge University Press.

7. Bengtsson BA, Brummer RJ, Eden S, Rosen T \& Sjostrom L (1992) Effects of growth hormone on fat mass and fat distribution. Acta Paediatr Suppl 383, 62-65.

8. Attallah H, Friedlander AL \& Hoffman AR (2006) Visceral obesity, impaired glucose tolerance, metabolic syndrome, and growth hormone therapy. Growth Horm IGF Res 16, Suppl. A, S62-S67.

9. Buijs MM, Burggraaf J, Langendonk JG et al. (2002) Hyposomatotropism blunts lipolysis in abdominally obese women. J Clin Endocrinol Metab 87, 3851-3858.

10. Pasarica M, Zachwieja JJ, Dejonge L, Redman S \& Smith SR (2007) Effect of growth hormone on body composition and visceral adiposity in middle aged men with visceral obesity. $J$ Clin Endocrinol Metab 92, 4265-4270.

11. Snel YE, Brummer RJ, Doerga ME, Zelissen PM, Bakker CJ, Hendriks MJ \& Koppeschaar HP (1995) Adipose tissue 
assessed by magnetic resonance imaging in growth hormone-deficient adults: the effect of growth hormone replacement and a comparison with control subjects. $A m \mathrm{~J}$ Clin Nutr 61, 1290-1294.

12. Smith WJ, Underwood LE \& Clemmons DR (1995) Effects of caloric or protein restriction on insulin-like growth factor-I (IGF-I) and IGF-binding proteins in children and adults. $J$ Clin Endocrinol Metab 80, 443-449.

13. Hoppe C, Molgaard C, Juul A \& Michaelsen KF (2004) High intakes of skimmed milk, but not meat, increase serum IGF-I and IGFBP-3 in eight-year-old boys. Eur J Clin Nutr 58, 1211-1216.

14. Rabinowitz D, Merimee TJ, Maffezzoli R \& Burgess JA (1966) Patterns of hormonal release after glucose, protein, and glucose plus protein. Lancet 2, 454-456.

15. Chromiak JA \& Antonio J (2002) Use of amino acids as growth hormone-releasing agents by athletes. Nutrition 18, 657-661.

16. Collier SR, Casey DP \& Kanaley JA (2005) Growth hormone responses to varying doses of oral arginine. Growth Horm IGF Res 15, 136-139.

17. Isidori A, Lo Monaco A \& Cappa M (1981) A study of growth hormone release in man after oral administration of amino acids. Curr Med Res Opin 7, 475-481.

18. Knopf RF, Conn JW, Fajans SS, Floyd JC, Guntsche EM \& Rull JA (1965) Plasma growth hormone response to intravenous administration of amino acids. J Clin Endocrinol Metab 25, 1140-1144.

19. Suminski RR, Robertson RJ, Goss FL, Arslanian S, Kang J, DaSilva S, Utter AC \& Metz KF (1997) Acute effect of amino acid ingestion and resistance exercise on plasma growth hormone concentration in young men. Int J Sport Nutr 7 , 48-60.

20. Welbourne TC (1995) Increased plasma bicarbonate and growth hormone after an oral glutamine load. Am J Clin Nutr 61, 1058-1061.

21. van Vught AJ, Nieuwenhuizen AG, Brummer RJ \& WesterterpPlantenga MS (2008) Effects of oral ingestion of amino acids and proteins on the somatotropic axis. J Clin Endocrinol Metab 93, 584-590.

22. van Vught AJ, Nieuwenhuizen AG, Veldhorst MAB, Brummer RJ \& Westerterp-Plantenga MS (2008) Somatotropic effects of the protein; soy, gelatin, alpha-lactalbumin and milk (Submitted).

23. Hasselstrom H, Karlsson KM, Hansen SE, Gronfeldt V, Froberg K \& Andersen LB (2006) Sex differences in bone size and bone mineral density exist before puberty. The Copenhagen School Child Intervention Study (CoSCIS). Calcif Tissue Int 79, 7-14.

24. Hasselstrom H, Karlsson KM, Hansen SE, Gronfeldt V, Froberg K \& Andersen LB (2007) Peripheral bone mineral density and different intensities of physical activity in children 6-8 years old: the Copenhagen School Child Intervention Study. Calcif Tissue Int 80, 31-38.
25. Lyhne N, Christensen T, Groth MV \& Fagt S (editors) (2005) Danskernes kostvaner 2000-2002. Soborg: Danmarks Fødevareforskning.

26. Moller A, Saxholt E, Christensen T \& Hartkopp H (2005) Fødevaredatabanken, version 6.0. Søborg: Danmarks Fødevareforskning. http://www.foodcomp.dk

27. Hoos MB, Kuipers H, Gerver WJ \& Westerterp KR (2004) Physical activity pattern of children assessed by triaxial accelerometry. Eur J Clin Nutr 58, 1425-1428.

28. Cole TJ, Bellizzi MC, Flegal KM \& Dietz WH (2000) Establishing a standard definition for child overweight and obesity worldwide: international survey. BMJ 320, 1240-1243.

29. Gnavi R, Spagnoli TD, Galotto C, Pugliese E, Carta A \& Cesari L (2000) Socioeconomic status, overweight and obesity in prepuberal children: a study in an area of Northern Italy. Eur J Epidemiol 16, 797-803.

30. Klein-Platat C, Wagner A, Haan MC, Arveiler D, Schlienger JL \& Simon C (2003) Prevalence and sociodemographic determinants of overweight in young French adolescents. Diabetes Metab Res Rev 19, 153-158.

31. Kristensen PL, Wedderkopp N, Moller NC, Andersen LB, Bai CN \& Froberg K (2006) Tracking and prevalence of cardiovascular disease risk factors across socio-economic classes: a longitudinal sub study of the European Youth Heart Study. BMC Public Health 6, 20.

32. Weststrate JA \& Deurenberg P (1989) Body composition in children: proposal for a method for calculating body fat percentage from total body density or skinfold-thickness measurements. Am J Clin Nutr 50, 1104-1115.

33. Wells JC \& Cole TJ (2002) Adjustment of fat-free mass and fat mass for height in children aged $8 \mathrm{y}$. Int J Obes Relat Metab Disord 26, 947-952.

34. Veldhuis JD, Roemmich JN, Richmond EJ, Rogol AD, Lovejoy JC, Sheffield-Moore M, Mauras N \& Bowers CY (2005) Endocrine control of body composition in infancy, childhood, and puberty. Endocr Rev 26, 114-146.

35. Fu WJ, Haynes TE, Kohli R, Hu J, Shi W, Spencer TE, Carroll RJ, Meininger CJ \& Wu G (2005) Dietary L-arginine supplementation reduces fat mass in Zucker diabetic fatty rats. J Nutr 135, 714-721.

36. Westerterp KR \& Goris AH (2002) Validity of the assessment of dietary intake: problems of misreporting. Current Opin Clin Nutr Metab Care 5, 489-493.

37. Heitmann BL \& Lissner L (1995) Dietary underreporting by obese individuals - is it specific or non-specific? BMJ 311, 986-989.

38. Livingstone MB \& Robson PJ (2000) Measurement of dietary intake in children. Proc Nutr Soc 59, 279-293.

39. Warren JM, Henry CJ, Livingstone MB, Lightowler HJ, Bradshaw SM \& Perwaiz S (2003) How well do children aged 5-7 years recall food eaten at school lunch? Public bealth nutrition $\mathbf{6}, 41-47$. 